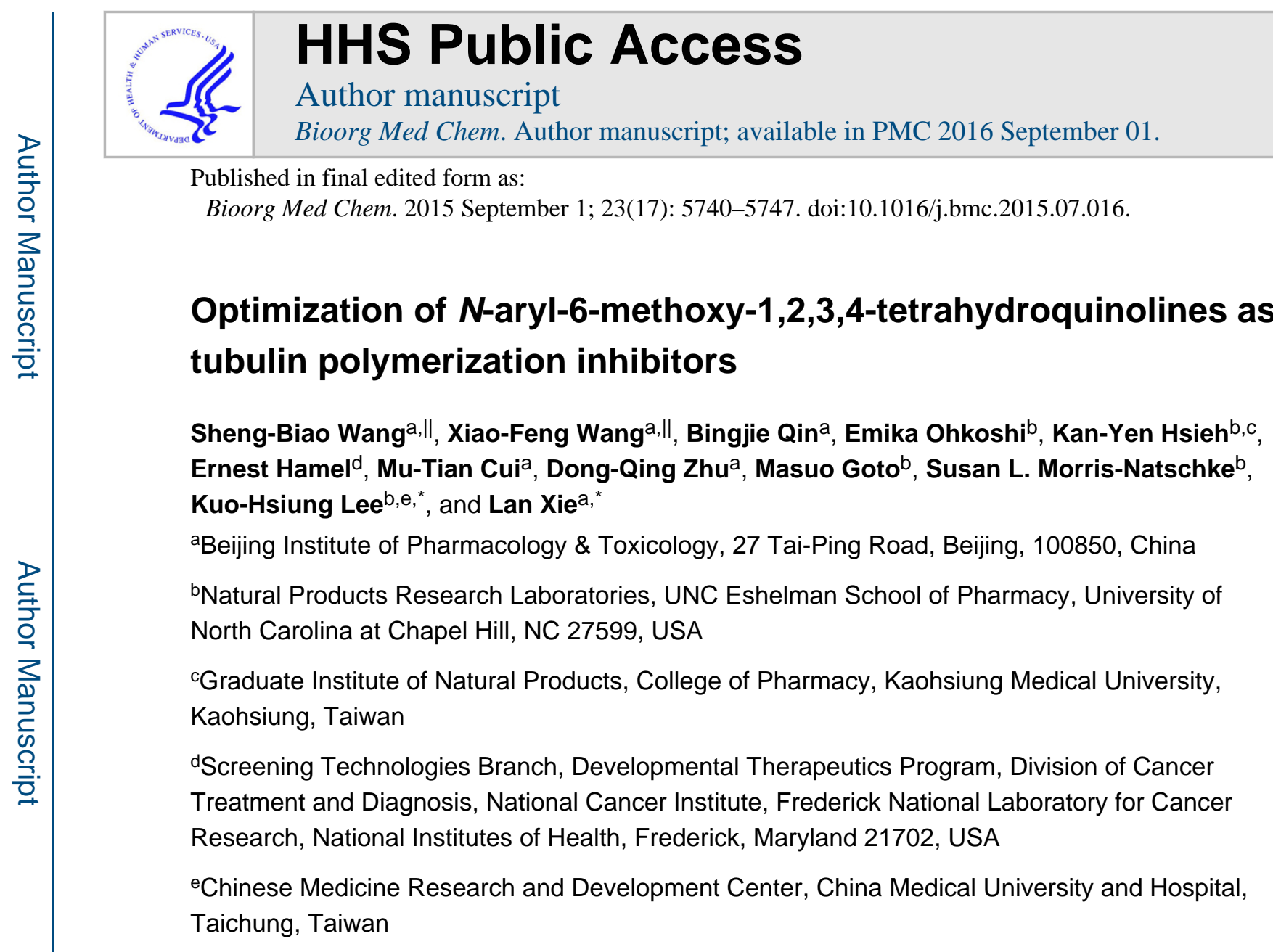

Published in final edited form as:

Bioorg Med Chem. 2015 September 1; 23(17): 5740-5747. doi:10.1016/j.bmc.2015.07.016.

\title{
Optimization of $\mathrm{N}$-aryl-6-methoxy-1,2,3,4-tetrahydroquinolines as tubulin polymerization inhibitors
}

\author{
Sheng-Biao Wang ${ }^{\mathrm{a}, \|}$, Xiao-Feng Wang ${ }^{\mathrm{a}, \|}$, Bingjie Qin ${ }^{\mathrm{a}}$, Emika Ohkoshi ${ }^{\mathrm{b}}$, Kan-Yen Hsieh ${ }^{\mathrm{b}, \mathrm{c}}$, \\ Ernest Hamel ${ }^{d}$, Mu-Tian Cui ${ }^{a}$, Dong-Qing Zhu ${ }^{a}$, Masuo Goto ${ }^{b}$, Susan L. Morris-Natschke ${ }^{b}$, \\ bNatural Products Research Laboratories, UNC Eshelman School of Pharmacy, University of \\ Graduate Institute of Natural Products, College of Pharmacy, Kaohsiung Medical University \\ dScreening Technologies Branch, Developmental Therapeutics Program, Division of Cancer \\ Treatment and Diagnosis, National Cancer Institute, Frederick National Laboratory for Cancer \\ Research, National Institutes of Health, Frederick, Maryland 21702, USA \\ Taichung, Taiwan
}

\begin{abstract}
Thirteen new $N$-aryl 1,2,3,4-tetrahydroquinoline compounds (4a-f, 6a-c, and 8a-d) were synthesized and evaluated for antitumor activity and drug-like properties. Compound $\mathbf{4 a}$ exhibited high inhibitory potency with low nanomolar $\mathrm{GI}_{50}$ values of $16-20 \mathrm{nM}$ in cellular assays, including excellent activity against the P-glycoprotein overexpressing cell line KBvin. Compound $\mathbf{4 a}$ inhibited colchicine binding to tubulin and tubulin assembly with an $\mathrm{IC}_{50}$ value of $0.85 \mu \mathrm{M}$, superior to the reference compound CA4 $(1.2 \mu \mathrm{M})$ in the same assay. In addition, $\mathbf{4 a}$ also exhibited highly improved water solubility $(75 \mu \mathrm{g} / \mathrm{mL})$ and a suitable $\log \mathrm{P}$ value (3.43) at $\mathrm{pH} 7.4$. With a good balance between antitumor potency and drug-like properties, compound $4 \mathbf{a}$ could be a new potential drug candidate for further development. Current results on SAR studies and molecular modeling provided more insight about this class of compounds as tubulin polymerization inhibitors targeting the colchicine site.
\end{abstract}

\section{Graphical Abstract}

\footnotetext{
*Corresponding authors: Tel/fax: +86 1066931690 (L. Xie); Tel: +1 919962 0066, fax: +1 919 966, 3893 (K.-H. Lee); lanxieshi@yahoo.com (L.Xie); khlee@unc.edu (K.-H. Lee).

The authors contributed equally to this work

Publisher's Disclaimer: This is a PDF file of an unedited manuscript that has been accepted for publication. As a service to our customers we are providing this early version of the manuscript. The manuscript will undergo copyediting, typesetting, and review of the resulting proof before it is published in its final citable form. Please note that during the production process errors may be discovered which could affect the content, and all legal disclaimers that apply to the journal pertain.
} 


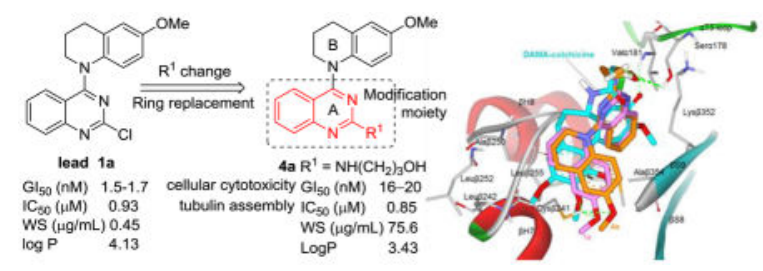

\section{Keywords}

$N$-Aryl 1,2,3,4-tetrahydroquinolines; Cytotoxic activity; Tubulin polymerization inhibitors; Colchicine binding inhibitors

\section{Introduction}

Microtubules play critical roles in cell division. They form the mitotic spindle, which directs and monitors the movement and attachment of chromosomes during mitosis and, thus, microtubules provide a target for anticancer drug development. The antitumor drugs paclitaxel and vinblastine, as well as related analogs, interfere with microtubule dynamics, ${ }^{1}$ either stabilizing microtubules or inhibiting tubulin polymerization, respectively, and are widely used as first-line drugs in clinical treatments. However, high toxicity and the development of drug resistance greatly limit their effectiveness. Recently, diverse small molecules binding at the colchicine site (CS) of tubulinn ${ }^{2,3,4}$ have undergone extensive development as vascular-disrupting agents (VDAs). ${ }^{5}$ VDAs with high cytotoxicity for human tumor cells target the vasculature induced by solid tumors, shut down blood flow to tumor cells, and cause cancer cell death via extensive necrosis and apoptosis, while blood flow in normal tissues remains relatively intact. ${ }^{6}$ A dozen VDA drug candidates targeted at the CS are currently in clinical development as cancer treatments, ${ }^{7,8}$ e.g., combretastatin A-4 (CA-4), its phosphate derivative CA-4P, ${ }^{9} \mathrm{BNC} 105,{ }^{10}$ and verubulin (MPC-6827), ${ }^{11}$ as shown in Figure 1, but none has an approved New Drug Application. Thus, continuous development of CS agents with novel structures or unique binding to the CS is needed to determine the optimal drug candidate.

In our prior studies on anticancer agents, ${ }^{12,13,14}$ we discovered new $N$-aryl 6methoxy-1,2,3,4- tetrahydroquinolines as potent tubulin polymerization inhibitors targeting the CS. We found high cytotoxicity in cellular assays and inhibitory potency in tubulin assembly and colchicine binding assays, resulting in two leads, $N$-( $2^{\prime}$-substitutedquinazol-4'-yl)-6-methoxy-1,2,3,4- tetrahydroquinolines $\mathbf{1 a}$ and $\mathbf{1 b}$ (Figure 2).

Subsequently, we performed structural optimizations on 1a, modifying either the piperidine ring (B-ring) or the quinozoline ring (A-ring), to elucidate structure-activity relationship (SAR) and structure-property relationship (SPR) correlations aimed at developing potential new drug candidates. The B-ring modification studies revealed some correlative SARs and resulted in promising potential drug candidates with a new scaffold and high antitumor potency in vitro and in vivo. ${ }^{15}$ Meanwhile, modifications on the quinazoline ring (A-ring) of 1a were also carried out in parallel, and related results are reported herein. Our continued optimization focused first on the 2-Cl group in 1a becuase of its chemical reactivity, which could lead to lower metabolic stability $\left(\mathbf{1 a}, \mathrm{t}_{1 / 2} 10.6 \mathrm{~min}\right)$ and present potential liability for 
further development. Because the previously synthesized 2-methylamino lead $\mathbf{1 b}$ exhibited improved aqueous solubility and metabolic stability compared with $\mathbf{1 a}$ (Figure 2$),{ }^{11}$ we postulated that the 2-substituent on the quinazoline ring (A ring) might improve drug-like properties without loss of antitumor potency. Therefore, we introduced several substituted amino or alkoxy groups at the 2-position on the quinazoline, resulting in new compounds 4a-f. Next, we replaced the quinazoline, a common moiety in many kinase inhibitors as well as the known VDA candidate MPC-6827, in 1a (Figure 1), with other bioisomeric heteroaromatic cyclic rings, such as unsubstituted and substituted purines (6 series), quinoline, and isoquinoline ( $\mathbf{8}$ series) (Figure 2), to explore new antitumor agents with different scaffold(s). Complementary to our prior structural optimizations, ${ }^{12}$ our current results with three new series 4,6 , and $\mathbf{8}$ are reported herein, including chemical synthesis, antitumor activity in vitro, drug-like property evaluation, molecular modeling, and SAR analysis.

\section{Chemistry}

The designed new $N^{1}$-aryl-6-methoxy-1,2,3,4-tetrahydroquinolines 4a-f and 6a-c were synthesized as shown in Schemes 1 and 2. According to previous methods, ${ }^{11}$ lead 1a was prepared by coupling 6-methoxy-1,2,3,4-tetrahydroquinoline (3) ${ }^{16}$ and 2,4dichloroquinazoline (2a) in the presence of $\mathrm{NaHCO}_{3}$ in anhydrous EtOH at reflux. Subsequently, the 2-chloro in 1a was converted to a substituted amino group by nucleophile reaction with 3-aminopropanol, cyclopropylamine, or cyclopenylamine in ethanol under microwave (mw) irradiation at $150{ }^{\circ} \mathrm{C}$ for $15 \mathrm{~min}$ to afford corresponding compounds $\mathbf{4 a - c}$, respectively, in yields ranging from 71 to $96 \%$. Under the same reaction conditions, compound $\mathbf{4 d}$ with a 2-dimethylamino group was obtained from 1a and DMF, serving as both dimethylamine source ${ }^{17}$ and solvent. Reaction of $\mathbf{1 a}$ with $\mathrm{NaOMe}$ in methanol at reflux produced 2-methoxyquinazoline compound $4 \mathbf{e}$ in $88 \%$ yield. While 1a was obtained under alkaline conditions, compound $\mathbf{3}$ was coupled with commercially available 4chloroquinazoline (2b) in the presence of $\mathrm{HCl}$ in $i-\mathrm{PrOH}$ at reflux to afford $\mathrm{N}$-(4quinazolyl)-6-methoxy-1,2,3,4- tetrahydroquinoline 4f. Similarly, $N^{l}$-(6-purinyl)-6methoxy-1,2,3,4-tetrahydroquinolines $\mathbf{6 a - c}$ were synthesized from 3 and a 6-chloro- $9 \mathrm{H}$ purine (5a, b or c) (Scheme 2). Finally, compound $\mathbf{3}$ was coupled with a halo-quinoline or isoquinoline (7a-d) in the presence of $\mathrm{Pd}(\mathrm{OAc})_{2}, \mathrm{X}$-phos (ratio 2\%-4\%), and $\mathrm{Cs}_{2} \mathrm{CO}_{3}$ in toluene at reflux to provide corresponding $N^{l}$-aryl substituted 6-methoxy-1,2,3,4tetrahydroquinolines 8a-d, respectively. All new target compounds 4, 6, and 8 were identified from ${ }^{1} \mathrm{H}$ NMR and MS spectroscopic data, and their purities were greater than 95\% as measured by HPLC.

\section{Results and discussion}

\subsection{Evaluation of cytotoxicity and tubulin inhibition activity in vitro}

The newly synthesized $N$-aryl substituted 6-methoxy-1,2,3,4-tetrahydroquinolines, series 4, $\mathbf{6}$ and $\mathbf{8}$, were first tested in cellular assays to evaluate in vitro antitumor activity. A panel of human tumor cell lines (HTCL) including A549 (lung carcinoma), KB (epidermoid carcinoma of the mouth), KBvin, a P-glycoprotein overexpressing multidrug-resistant cell line (vincristine-resistant KB), ${ }^{18,19}$ and DU145 (prostate cancer) was used with paclitaxel as 
a reference. The potency $\left(\mathrm{GI}_{50}\right)$ in vitro was determined using the established sulforhodamine B (SRB) method, ${ }^{20}$ and data are shown in Tables 1 and 2.

All six series 4 compounds with a 2-substituted quinazoline B-ring system exhibited significant cytotoxicity against the growth of the tested HTCL (Table 1). Among them, compounds $\mathbf{4 a}, \mathbf{b}, \mathbf{e}$, and $\mathbf{f}$ showed low nanomolar $\mathrm{GI}_{50}$ values ranging from 13 to $30 \mathrm{nM}$, comparable to lead $\mathbf{1 b}$ but less potent than $\mathbf{1 a}(1.5-1.7 \mathrm{nM})$. With low to sub-micromolar $\mathrm{GI}_{50}$ values $(0.14-1.42 \mu \mathrm{M})$, the 2-cyclopentylamino- (4c) and 2- $N, N$-dimethylamino (4d)

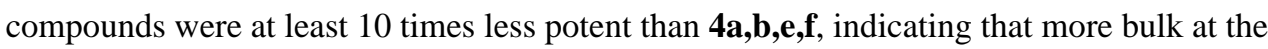
2-position on the quinazoline was not favorable for cytotoxic activity. Furthermore, potency dropped dramatically when the quinazoline moiety was replaced by a purine without or with a substituent $\left(\mathbf{6 a}-\mathbf{c}, \mathrm{GI}_{50}>17.53 \mu \mathrm{M}\right)($ Table 1$)$. However, compounds 8a-c with a quinoline or isoquinoline rather than quinazoline showed moderate cytotoxicity with $\mathrm{GI}_{50}$ values of $0.16-2.08 \mu \mathrm{M}$, while $8 \mathbf{d}$ was less potent $\left(\mathrm{GI}_{50} 8.71-16.2 \mu \mathrm{M}\right)$ in the cellular assay (Table 2). These results indicated that the quinazoline ring could be changed, but more investigations are warranted.

The data in Tables 1 and 2 also demonstrate that all newly synthesized compounds, unlike paclitaxel, have equivalent activities in the KB and KBvin cell lines. The latter overexpresses the drug transporter P-glycoprotein, resulting in a multidrug resistant phenotype.

Next, selected compounds from the cellular cytotoxicity assays were evaluated in tubulin assembly inhibition and colchicine binding assays for comparison with the control CA-4, a phase III clinical candidate. These data are shown in Table 3 . As expected, the most cytotoxic compounds $\mathbf{4 a}, \mathbf{4 b}$, and $\mathbf{4 f}$ also exhibited high potency in the tubulin assembly assay with low micromolar $(1.3 \mu \mathrm{M}, \mathbf{4 b}$ and $\mathbf{4 f})$ or sub-micromolar $(0.85 \mu \mathrm{M}, \mathbf{4 a}) \mathrm{IC}_{50}$ values, comparable with or better than the value obtained with $\mathrm{CA} 4\left(\mathrm{IC}_{50} 1.2 \mu \mathrm{M}\right)$. The three compounds also inhibited colchicine binding to tubulin. In addition, the moderately potent compounds $\mathbf{4 c}, \mathbf{8 a}$, and $\mathbf{8 b}\left(\mathrm{GI}_{50}\right.$ values, $\left.0.92-2.08 \mu \mathrm{M}\right)$ and less active compound $\mathbf{8 d}$ $\left(\mathrm{GI}_{50} 8.71-16.2 \mu \mathrm{M}\right)$ from the cellular cytotoxicity assay were also tested against tubulin assembly and colchicine binding in cell-free assays. Compared with $\mathbf{4 a}, \mathbf{4 b}$, and $\mathbf{4 f}$, compounds $\mathbf{4 c}, \mathbf{8 a}, \mathbf{8 b}$ showed lower potency, with assembly $\mathrm{IC}_{50}$ values ranging from 2.6 to $5.7 \mu \mathrm{M}$ and less than $40 \%$ inhibition of colchicine binding at $5 \mu \mathrm{M}$, whereas $8 \mathbf{d}$ did not display significant inhibitory activity in the assembly assay. The consistency of the results between the cellular and cell-free assays, as well as with our previous results, confirms that our new active compounds are tubulin polymerization inhibitors targeting the CS.

Next, selected compounds from the cellular cytotoxicity assays were evaluated in tubulin assembly inhibition and colchicine binding assays for comparison with the control CA-4, a phase III clinical candidate. These data are shown in Table 3. As expected, the most cytotoxic compounds $\mathbf{4 a}, \mathbf{4 b}$, and $\mathbf{4 f}$ also exhibited high potency in the tubulin assembly assay with low micromolar $(1.3 \mu \mathrm{M}, \mathbf{4 b}$ and $\mathbf{4 f})$ or sub-micromolar $(0.85 \mu \mathrm{M}, \mathbf{4 a}) \mathrm{IC}_{50}$ values, comparable with or better than the value obtained with CA4 ( $\left.\mathrm{IC}_{50} 1.2 \mu \mathrm{M}\right)$. The three compounds also inhibited colchicine binding to tubulin. In addition, the moderately potent compounds $\mathbf{4 c}, \mathbf{8 a}$, and $\mathbf{8 b}\left(\mathrm{GI}_{50}\right.$ values, $\left.0.92-2.08 \mu \mathrm{M}\right)$ and less active compound $\mathbf{8 d}$ 
$\left(\mathrm{GI}_{50} 8.71-16.2 \mu \mathrm{M}\right)$ from the cellular cytotoxicity assay were also tested against tubulin assembly and colchicine binding in cell-free assays. Compared with $\mathbf{4 a}, \mathbf{4 b}$, and $\mathbf{4 f}$, compounds $\mathbf{4 c}, \mathbf{8 a}, \mathbf{8 b}$ showed lower potency, with assembly $\mathrm{IC}_{50}$ values ranging from 2.6 to $5.7 \mu \mathrm{M}$ and less than $40 \%$ inhibition of colchicine binding at $5 \mu \mathrm{M}$, whereas $\mathbf{8 d}$ did not display significant inhibitory activity in the assembly assay. The consistency of the results between the cellular and cell-free assays, as well as with our previous results, confirms that our new active compounds are tubulin polymerization inhibitors targeting the CS.

\subsection{Physicochemical property evaluations}

Representative active compounds $\mathbf{4 a}$ and $\mathbf{4 b}$ were further evaluated for aqueous solubility, which is good drug-like property, especially for antitumor drugs given via intravenous administration, and $\log \mathrm{P}$ parameters at $\mathrm{pH} 7.4$ by using HPLC methodology. ${ }^{21}$ As expected, compared with $\mathbf{1 a}(0.45 \mu \mathrm{g} / \mathrm{mL})$, compound $\mathbf{4 a}$, with a polar 2-hydroxypropylamino group on the quinazoline, showed greatly improved aqueous solubility $(75.6 \mu \mathrm{g} / \mathrm{mL})$, while compound $\mathbf{4 b}$ with the more lipophilic 2-cyclopropylamino group displayed less improved aqueous solubility $(2.55 \mu \mathrm{g} / \mathrm{mL}$ ) (Table 4$)$. Consistent with the solubility results, $\mathbf{4 a}$ had a more suitable $\log \mathrm{P}$ value (3.45) than $\mathbf{4 b}(\log \mathrm{P} 4.13)$. Therefore, compound $\mathbf{4 a}$ could be a potential anticancer drug candidate for further development by evaluating its in vivo activity.

\subsection{Molecular modeling}

In an attempt to better understand the molecular basis of $\mathbf{4 a}$ as a tubulin inhibitor, we modeled compound $\mathbf{4 a}$ into the CS in the tubulin dimer by using the CDOCKER program in the Discovery Studio 3.0 software with the tubulin crystal structure (PDB: 1SA0). ${ }^{22}$ As shown in Figure 3, the binding conformation of $\mathbf{4 a}$ (orange) displayed a lower energy $(-46.11 \mathrm{kcal} / \mathrm{mol})$ than lead $\mathbf{1 a}(-38.68 \mathrm{kcal} / \mathrm{mol})$ and superimposed well with $1 \mathbf{a}$ (pink) and original ligand DAMA-colchicine (cyan) in the tubulin crystal structure. From literature reports, ${ }^{23,24}$ Cys 241 in $\beta-\mathrm{H} 7$ of tubulin is a key amino acid that anchors most inhibitors, and its side chain forms a hydrogen bond with the oxygen atom of the $2-\mathrm{OCH}_{3}$ on the phenyl ring (C-ring) of DAMA-colchicine. Like lead 1a, compound $\mathbf{4 a}$ also formed a hydrogen bond from the 6- $\mathrm{OCH}_{3}$ group on the tetrahydroquinoline ring (B/C-ring) with Cys241. The tetrahydroquinoline ring in $\mathbf{4 a}$ and $\mathbf{1 a}$ overlapped well with the trimethoxyphenyl portion of DAMA-colchicine. Meanwhile, the cyclic linker in $\mathbf{4 a}$ extended toward a lipophilic cavity surrounded with lipophilic amino acid residues, Leuß242, Alaß250, Leuß252 and Leuß255, but only Leu $\beta 255$ was close enough to the cyclic linker to be within distance of van der Waal's force. Thus, we suggest that the cyclic linker could be further modified to have more interactions with the lipophilic cavity to enhance the affinity of this compound type with the colchicine binding site of tubulin. Compared with 1a, the terminal hydroxy group of the 2substituent on the quinazoline ring of $\mathbf{4 a}$ formed an additional hydrogen bond with Ser178 in the a-T5 loop of tubulin. Although these hydrogen bonds between tubulin and the thiol group of DAMA-colchicine were observed, intact colchicine may not form these hydrogen bonds. Additionally, we observed that the linear 2-hydroxypropylamino group in 4a was oriented similarly to the mercaptoacetamido $\left(-\mathrm{HNCOCH}_{2} \mathrm{SH}\right)$ group in DAMA-colchicine, and both superimposed well. Thus, the flexible 2-hydroxypropylamino group could attain a 
suitable conformation to interact with amino acids of the tubulin binding site to enhance molecular affinity.

\section{Conclusion}

By modifying the quinazoline ring moiety of lead 1a, we synthesized 13 new 1,2,3,4tetrahydroquinoline compounds, $\mathbf{4 a - f}, \mathbf{6 a}-\mathbf{c}$, and $\mathbf{8 a - d}$, with various $N$-aryl substituents. Compound $4 \mathbf{a}$ showed high inhibitory potency in the tubulin polymerization assay $\left(\mathrm{IC}_{50}\right.$ $0.85 \mu \mathrm{M})$, targeting the $\mathrm{CS}$, with greater potency than the reference compound CA-4 (1.2 $\mu \mathrm{M})$. Compound $4 \mathrm{a}$ also strongly inhibited the growth of human tumor cells with low nanomolar $\mathrm{GI}_{50}$ values (16-20 nM). Compound 4a was fully active in a multidrug resistant cell line overexpressing P-glycoprotein. Notably, active compound $\mathbf{4 a}$ also exhibited highly improved water solubility $(75 \mu \mathrm{g} / \mathrm{mL})$ and a suitable $\log \mathrm{P}$ value (3.43) at $\mathrm{pH} 7.4$ that are better than those of lead 1a and other new compounds. Thus, compound $4 \mathbf{a}$ could be a potential drug candidate for further development. Meanwhile, the current results also revealed additional SAR information. (1) The 2-substituent on the quinazoline ring is modifiable to enhance or maintain molecular antitumor activity $(\mathbf{4 a}-\mathbf{b}, \mathbf{4 e - f})$, but a bulky group is unfavorable (4c and $\mathbf{4 d}$ ). (2) The quinazoline ring is a better moiety than purine (cf. $\mathbf{6}$ series, which exhibited much lower activity) for antitumor activity but is replaceable (cf. 8 series with quinoline or isoquinoline ring, which maintained low micromolar $\mathrm{GI}_{50}$ values). (3) The polar hydroxypropylamino substituent is favorable due to its flexibility and H-bond forming ability, resulting in a good balance between potency and drug-like properties. Molecular modeling results provided additional insight on the interactions of $4 \mathbf{a}$ with the tubulin colchicine site. These current results complement our prior studies and will help us to further optimize and develop new drug candidates for clinical studies as novel tubulin inhibitors targeting the CS.

\section{Experimental section}

\subsection{Chemistry}

All commercial chemical reagents were purchased from Beijing Chemical Works or SigmaAldrich, Inc. Proton nuclear magnetic resonance ( ${ }^{1} \mathrm{H}$ NMR) spectra were measured on a JNM-ECA-400 (400MHz) spectrometer using tetramethylsilane (TMS) as internal standard. The solvent used was $\mathrm{CDCl}_{3}$ unless otherwise indicated. Mass spectra (MS) were measured on an API-150 mass spectrometer with an electrospray ionizer from ABI, Inc., and data are presented as intensity of ion peak (\%). Melting points were measured by a SGW X-4 MicroMelting point detector without correction. Microwave-assisted reactions were performed on a reactor from Biotage, Inc. Medium-pressure column chromatography was performed using a CombiFlash Companion system from ISCO, Inc. Thin-layer chromatography (TLC) was performed on silica gel GF254 plates. Aqueous solubility and $\log$ P of target compounds were determined by using an Agilent 1200 HPLC system with UV detector and an Agilent Eclipse XDB-C18 column $(4.6 \times 150 \mathrm{~mm}, 5 \mu \mathrm{m})$, flow rate $0.8 \mathrm{~mL} / \mathrm{min}$, UV detection at $254 \mathrm{~nm}$, and injection volume of $20 \mu \mathrm{L}$. The mobile elution is a mixture of solvents $\mathrm{MeOH}$ and water (80:20) contained $0.04 \%$ ammonium acetate. The purity of target compounds was also measured by HPLC using the above conditions, unless otherwise indicated. The preparation of 1a was reported in our previous publication. ${ }^{11}$ 


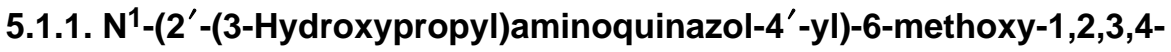
tetrahydro- quinoline (4a)-A mixture of $1 \mathbf{a}(145 \mathrm{mg}, 0.44 \mathrm{mmol})$ and 3-aminopropanol $(0.1 \mathrm{~mL}$, excess $)$ in EtOH $(2.5 \mathrm{~mL})$ was stirred under mw irradiation at $150^{\circ} \mathrm{C}$ for $15 \mathrm{~min}$. The mixture was poured into ice-water, extracted with EtOAc, and washed with water to neutral. After removal of solvent, crude product was purified on a silica column with gradient elution $\left(\mathrm{MeOH} / \mathrm{CH}_{2} \mathrm{Cl}_{2} 0-5 \%\right)$ by a CombiFlash system to produce $137 \mathrm{mg}$ of $4 \mathbf{a}$ in 71\% yield, yellow solid, mp 134 136 ${ }^{\circ} \mathrm{C} ;{ }^{1} \mathrm{H}$ NMR $\delta$ ppm $1.77\left(2 \mathrm{H}, \mathrm{t}, J=7.2 \mathrm{~Hz}, \mathrm{CH}_{2}\right)$, $2.07\left(2 \mathrm{H}, \mathrm{m}, 3-\mathrm{CH}_{2}\right), 2.85\left(2 \mathrm{H}, \mathrm{t}, J=6.8 \mathrm{~Hz}, \mathrm{PhCH}_{2}\right), 3.67\left(4 \mathrm{H}, \mathrm{m}, 2 \times \mathrm{CH}_{2}\right), 3.79(3 \mathrm{H}, \mathrm{s}$, $\left.\mathrm{OCH}_{3}\right), 3.93\left(2 \mathrm{H}, \mathrm{t}, J=6.8 \mathrm{~Hz}, 2-\mathrm{NCH}_{2}\right), 6.56(1 \mathrm{H}, \mathrm{dd}, J=8.8$ and $2.8 \mathrm{~Hz}, \mathrm{PhH}-7), 6.70$ $(1 \mathrm{H}, \mathrm{d}, J=8.8 \mathrm{~Hz}, \mathrm{PhH}-8), 6.77(1 \mathrm{H}, \mathrm{d}, J=2.8 \mathrm{~Hz}, \mathrm{PhH}-5), 6.84(1 \mathrm{H}, \mathrm{m}, \mathrm{ArH}-6), 7.25(1 \mathrm{H}$, d, $J=8.0 \mathrm{~Hz}, \operatorname{ArH}-5), 7.47$ (2H, m, ArH-7,8), MS m/z (\%) $365(\mathrm{M}+\mathrm{H})^{+;}{ }^{13} \mathrm{C} \mathrm{NMR} \delta \mathrm{ppm}$ 24.10, 27.11, 33.90, 37.01, 47.38, 55.39, 57.76, 111.86, 113.34, 120.76, 122.95, 124.99, 126.54, 132.16, 132.79 (C×2), 135.67, 152.78, 155.87, 159.78, and 163.02; HPLC purity $98.9 \%$.

\subsection{2. $\mathbf{N}^{1}$-(2' - Cyclopropylaminoquinazol-4' ${ }^{\prime}$-yl)-6-methoxy-1,2,3,4-} tetrahydroquinoline (4b)—Prepared in the same manner as $\mathbf{4 a}$. Starting with $\mathbf{1 a}$ (50 mg, $0.15 \mathrm{mmol})$ and cyclopropanamine $(0.1 \mathrm{~mL}$, excess $)$ in EtOH $(2.5 \mathrm{~mL})$ under mw irradiation at $150{ }^{\circ} \mathrm{C}$ for $15 \mathrm{~min}$ to provide $51 \mathrm{mg}$ of $\mathbf{4 b}$ in $97 \%$ yield, yellow solid, mp $173 \sim 175{ }^{\circ} \mathrm{C} ;{ }^{1} \mathrm{H}$ NMR (DMSO- $\left.d_{6}\right) \delta$ ppm $0.51\left(2 \mathrm{H}, \mathrm{m}, \mathrm{CH}_{2}\right), 0.66\left(2 \mathrm{H}, \mathrm{m}, \mathrm{CH}_{2}\right), 1.97\left(2 \mathrm{H}, \mathrm{m}, 3-\mathrm{CH}_{2}\right), 2.81$ $\left(3 \mathrm{H}, \mathrm{m}, \mathrm{PhCH}_{2}\right.$ and $\left.\mathrm{CH}\right), 3.71\left(3 \mathrm{H}, \mathrm{s}, \mathrm{OCH}_{3}\right), 3.82\left(2 \mathrm{H}, \mathrm{t}, J=6.4 \mathrm{~Hz}, 2-\mathrm{CH}_{2} \mathrm{~N}\right), 6.56(1 \mathrm{H}$, $\mathrm{dd}, J=8.8$ and $2.4 \mathrm{~Hz}, \mathrm{PhH}-7), 6.68(1 \mathrm{H}, \mathrm{d}, J=8.8 \mathrm{~Hz}, \mathrm{PhH}-8), 6.76(1 \mathrm{H}, \mathrm{d}, J=2.4 \mathrm{~Hz}$, PhH-5), 6.84 (1H, m, ArH-6), 7.29 (1H, d, $J=8.8 \mathrm{~Hz}$, ArH-5), 7.45 (1H, m, ArH-7), $7.54(1 \mathrm{H}, \mathrm{d}, J=8.8 \mathrm{~Hz}, \mathrm{ArH}-8)$; MS $m / z(\%) 347(\mathrm{M}+\mathrm{H})^{+}$; HPLC purity $95.2 \%$.

\subsection{3. $\mathbf{N}^{1}-\left(2^{\prime}\right.$-Cyclopentyl)aminoquinazol-4' $\left.-\mathrm{yl}\right)-6-$ methoxy-1,2,3,4-}

tetrahydroquinoline (4c)-Prepared in the same manner as 4a. Starting with $1 \mathbf{a}(150 \mathrm{mg}$, $0.45 \mathrm{mmol})$ and cyclopentanamine $(0.1 \mathrm{~mL}$, excess $)$ in $\mathrm{EtOH}(2.5 \mathrm{~mL})$ under mw irradiation at $150{ }^{\circ} \mathrm{C}$ for $15 \mathrm{~min}$ to afford $138 \mathrm{mg}$ of $\mathbf{4 c}$ in $80 \%$ yield, yellow solid, mp $178 \sim 180{ }^{\circ} \mathrm{C} ;{ }^{1} \mathrm{H}$ NMR (DMSO- $\left.d_{6}\right) \delta$ ppm $1.54\left(4 \mathrm{H}, \mathrm{m}, 2 \times \mathrm{CH}_{2}\right), 1.68\left(2 \mathrm{H}, \mathrm{m}, \mathrm{CH}_{2}\right), 1.92\left(2 \mathrm{H}, \mathrm{m}, \mathrm{CH}_{2}\right), 1.98$ $\left(2 \mathrm{H}, \mathrm{m}, 3-\mathrm{CH}_{2}\right), 2.81\left(2 \mathrm{H}, \mathrm{t}, J=6.8 \mathrm{~Hz}, \mathrm{PhCH}_{2}\right), 3.71\left(3 \mathrm{H}, \mathrm{s}, \mathrm{OCH}_{3}\right), 3.82(2 \mathrm{H}, \mathrm{t}, J=6.8$ $\left.\mathrm{Hz}, \mathrm{NCH}_{2}\right), 4.28(1 \mathrm{H}, \mathrm{m}, \mathrm{CH}), 6.55(1 \mathrm{H}, \mathrm{dd}, J=8.8$ and $2.4 \mathrm{~Hz}, \mathrm{PhH}-7), 6.68(1 \mathrm{H}, \mathrm{d}, J=$ $8.8 \mathrm{~Hz}, \mathrm{PhH}-8), 6.78(1 \mathrm{H}, \mathrm{d}, J=2.4 \mathrm{~Hz}, \mathrm{PhH}-5), 6.88(1 \mathrm{H}, \mathrm{m}, \mathrm{ArH}-6), 7.24(1 \mathrm{H}, \mathrm{d}, J=8.8$ $\mathrm{Hz}, \mathrm{ArH}-5), 7.45$ (1H, m, ArH-7), 7.54 (1H, d, $J=8.8 \mathrm{~Hz}, \mathrm{ArH}-8) ;{ }^{13} \mathrm{C}$ NMR $\delta p p m 23.88$ (C×2), 24.28, 27.38, 33.68 (C×2), 47.39, 53.01, 55.53, 111.86, 113.44, 120.21, 122.67, $125.84,126.58,131.86,132.44(\mathrm{C} \times 2), 136.38,154.37,155.57,159.25$, and 163.14; MS $\mathrm{m} / \mathrm{z}$ (\%) $375(\mathrm{M}+\mathrm{H})^{+}$; HPLC purity $99.2 \%$ (elution $\mathrm{CH}_{3} \mathrm{CN} /$ water 70:30).

\subsection{4. $\mathrm{N}^{1}$-(2'-Dimethylaminoquinazol-4' $\left.-\mathrm{yl}\right)-6-$ methoxy-1,2,3,4-} tetrahydroquinoline (4d)-A solution of $1 \mathbf{a}(50 \mathrm{mg}, 0.15 \mathrm{mmol})$ in DMF $(2 \mathrm{~mL})$ in the presence of $0.1 \mathrm{~mL}$ of ammonium hydroxide $\left(\mathrm{NH}_{3} \cdot \mathrm{H}_{2} \mathrm{O}\right)$ was heated with stirring under mw irradiation at $150{ }^{\circ} \mathrm{C}$ for $15 \mathrm{~min}$. The mixture was poured into ice-water, and a yellow solid was filtered and washed with water until neutral. The crude product was purified by a flash chromatography (gradiant elution: $\mathrm{MeOH} / \mathrm{CH}_{2} \mathrm{Cl}_{2} \mathrm{O}-5 \%$ ) to provide $45 \mathrm{mg}$ of $\mathbf{4 d}$ in $88 \%$ yield, light yellow solid, mp 89 91 ${ }^{\circ} \mathrm{C} ;{ }^{1} \mathrm{H}$ NMR $\delta$ ppm $2.08\left(2 \mathrm{H}, \mathrm{m}, 3-\mathrm{CH}_{2}\right), 2.85(2 \mathrm{H}, \mathrm{t}, J$ 
$\left.=6.8 \mathrm{~Hz}, \mathrm{PhCH}_{2}\right), 3.27\left(6 \mathrm{H}, \mathrm{s}, 2 \times \mathrm{NCH}_{3}\right), 3.78\left(3 \mathrm{H}, \mathrm{s}, \mathrm{OCH}_{3}\right), 3.97(2 \mathrm{H}, \mathrm{t}, J=6.8 \mathrm{~Hz}$, $\left.\mathrm{NCH}_{2}\right), 6.53(1 \mathrm{H}, \mathrm{dd}, J=8.8$ and $2.8 \mathrm{~Hz}, \mathrm{PhH}-7), 6.65(1 \mathrm{H}, \mathrm{d}, J=8.8 \mathrm{~Hz}, \mathrm{PhH}-8), 6.77(2 \mathrm{H}$, m, PhH-5 and ArH-6), 7.23 (1H, d, $J=8.0 \mathrm{~Hz}, \mathrm{ArH}-5), 7.42(1 \mathrm{H}, \mathrm{m}, \mathrm{ArH}-7), 7.50(1 \mathrm{H}, \mathrm{d}, J$ $=8.0 \mathrm{~Hz}, \mathrm{ArH}-8) ; \mathrm{MS} m / z(\%) 335(\mathrm{M}+\mathrm{H})^{+}$; HPLC purity $97.5 \%$.

\subsection{5. $\mathrm{N}^{1}$-(2'-Methoxyquinazol-4' $\left.-\mathrm{yl}\right)$-6-methoxy-1,2,3,4-tetrahydroquinoline} (4e)-A mixture of 1a (81 mg, $0.25 \mathrm{mmol})$ in anhydrous $\mathrm{MeOH}(4 \mathrm{~mL})$ and $\mathrm{NaOMe}(34$ $\mathrm{mg}, 0.62 \mathrm{mmol}$ ) was refluxed for $1 \mathrm{~h}$. The mixture was poured into ice-water with stirring and neutralized with $\mathrm{HCl}(2 \mathrm{~N})$. The solid product was collected on a filter, washed with water until neutral, and dried to obtain $71 \mathrm{mg}$ of pure $4 \mathrm{e}, 88 \%$ yield, pale yellow solid, $\mathrm{mp}$ 161-163 ${ }^{\circ} \mathrm{C} ;{ }^{1} \mathrm{H}$ NMR $\delta$ ppm $2.09\left(2 \mathrm{H}, \mathrm{m}, 3-\mathrm{CH}_{2}\right), 2.85\left(2 \mathrm{H}, \mathrm{t}, J=6.8 \mathrm{~Hz}, \mathrm{PhCH}_{2}\right), 3.80$ $\left.\left(3 \mathrm{H}, \mathrm{s}, \mathrm{OCH}_{3}\right), 4.03\left(2 \mathrm{H}, \mathrm{t}, J=6.8 \mathrm{~Hz}, \mathrm{NCH}_{2}\right),\right), 4.09\left(3 \mathrm{H}, \mathrm{s}, \mathrm{OCH}_{3}\right), 6.53(1 \mathrm{H}, \mathrm{dd}, J=8.8$ and $2.8 \mathrm{~Hz}, \mathrm{PhH}-7), 6.67(1 \mathrm{H}, \mathrm{d}, J=8.8 \mathrm{~Hz}, \mathrm{PhH}-8), 6.79(1 \mathrm{H}, J=2.8 \mathrm{~Hz}, \mathrm{PhH}-5), 6.98$ $(1 \mathrm{H}, \mathrm{m}, \mathrm{ArH}-6), 7.23$ (1H, d, $J=8.4 \mathrm{~Hz}$, ArH-5), $7.56(1 \mathrm{H}, \mathrm{m}, \mathrm{ArH}-7), 7.68(1 \mathrm{H}, \mathrm{d}, J=8.4$ $\mathrm{Hz}, \mathrm{ArH}-8) ; \mathrm{MS} m / z(\%) 322(\mathrm{M}+\mathrm{H})^{+}$; HPLC purity $98.8 \%$.

5.1.6. 6-Methoxy-N $\mathbf{N}^{\mathbf{1}}$-( $\mathbf{4}^{\prime}$-quinazolyl)-1,2,3,4-tetrahydroquinoline (4f)-A mixture of 4-chloroquinazoline (2b, $170 \mathrm{mg}, 1.04 \mathrm{mmol}$ ) and 6-methoxy-1,2,3,4-tetrahydroquinoline $(3,180 \mathrm{mg}, 1.10 \mathrm{mmol})$ in $i-\mathrm{PrOH}(15 \mathrm{~mL})$ with a drop of $\mathrm{HCl}$ (conc.) was refluxed for $1 \mathrm{~h}$ monitored by TLC until the reaction was completed. The mixture was poured into ice-water, adjusted to neutral $\mathrm{pH}$ with $\mathrm{NaHCO}_{3}$, extracted with EtOAc three times, and dried over anhydrous $\mathrm{Na}_{2} \mathrm{SO}_{4}$. After removal of solvent, the product was purified on a silica chromatographic column with gradient elution $\left(\mathrm{MeOH} / \mathrm{CH}_{2} \mathrm{Cl}_{2} 0-5 \%\right)$ to furnish $193 \mathrm{mg}$ of $4 \mathbf{f}$ in $65 \%$ yield, light yellow solid, mp 94 95 ${ }^{\circ} \mathrm{C} ;{ }^{1} \mathrm{H}$ NMR $\delta \mathrm{ppm} 2.11(2 \mathrm{H}, \mathrm{t}, J=6.8 \mathrm{~Hz}, 3-$ $\left.\mathrm{CH}_{2}\right), 2.87\left(2 \mathrm{H}, \mathrm{t}, J=6.8 \mathrm{~Hz}, 4-\mathrm{CH}_{2}\right), 3.80\left(3 \mathrm{H}, \mathrm{s}, \mathrm{OCH}_{3}\right), 4.05\left(2 \mathrm{H}, \mathrm{t}, J=6.8 \mathrm{~Hz}, 2-\mathrm{CH}_{2}\right)$, $6.56(1 \mathrm{H}, \mathrm{dd}, J=8.8$ and $2.8 \mathrm{~Hz}, \mathrm{PhH}-7), 6.65(1 \mathrm{H}, \mathrm{d}, J=8.8 \mathrm{~Hz}, \mathrm{PhH}-8), 6.79(1 \mathrm{H}, \mathrm{d}, J=$ $2.8 \mathrm{~Hz}, \mathrm{PhH}-5), 7.21(1 \mathrm{H}, \mathrm{t}, J=8.8 \mathrm{~Hz}, \mathrm{ArH}-6), 7.49(1 \mathrm{H}, \mathrm{d}, J=8.8 \mathrm{~Hz}, \mathrm{ArH}-5), 7.68(1 \mathrm{H}$, $\mathrm{t}, J=8.8 \mathrm{~Hz}, \mathrm{ArH}-7), 7.89(1 \mathrm{H}, \mathrm{d}, J=8.8 \mathrm{~Hz}, \mathrm{ArH}-8), 8.86(1 \mathrm{H}, \mathrm{s}, \mathrm{ArH}-2) ; \mathrm{MS} m / z(\%)$ $292.2(\mathrm{M}+\mathrm{H})^{+} ;$HPLC purity $98.4 \%$.

5.1.7. $\mathrm{N}^{1}$-(6-Purin-9H-yl)-6-methoxy-1,2,3,4-tetrahydroquinoline (6a)-A mixture of $\mathbf{3}(180 \mathrm{mg}, 1.10 \mathrm{mmol})$ and 6-chloro-9H-purine (5a, $150 \mathrm{mg}, 0.97 \mathrm{mmol})$ in $i$-propanol $(15 \mathrm{~mL})$ in the presence of 1 drop of $\mathrm{HCl}$ (conc.) was refluxed for $5 \mathrm{~h}$. When the reaction was complete, the mixture was poured into ice-water, adjusted to neutral $\mathrm{pH}$, extracted with EtOAc, and dried over anhydrous $\mathrm{Na}_{2} \mathrm{SO}_{4}$. After removal of solvent in vacuo, crude product was purified by flash silica column chromatography (gradient elution: $\mathrm{MeOH} / \mathrm{CH}_{2} \mathrm{Cl}_{2}, 0$ $5 \%$ ) to produce $201 \mathrm{mg}$ of $\mathbf{6 a}$ in $74 \%$ yield, white solid, mp 189 191 ${ }^{\circ} \mathrm{C} ;{ }^{1} \mathrm{H}$ NMR $\delta \mathrm{ppm}$ $2.10\left(2 \mathrm{H}, \mathrm{m}, 3-\mathrm{CH}_{2}\right), 2.87\left(2 \mathrm{H}, \mathrm{t}, J=6.4 \mathrm{~Hz}, \mathrm{PhCH}_{2}\right), 3.82\left(3 \mathrm{H}, \mathrm{s}, \mathrm{OCH}_{3}\right), 4.59(2 \mathrm{H}, \mathrm{t}, J=$ $\left.6.4 \mathrm{~Hz}, \mathrm{NCH}_{2}\right), 6.73(1 \mathrm{H}, \mathrm{s}, \mathrm{PhH}-5), 6.77(1 \mathrm{H}, \mathrm{dd}, J=8.8$ and $2.4 \mathrm{~Hz}, \mathrm{PhH}-7), 7.52(1 \mathrm{H}, \mathrm{d}$, $J=8.8 \mathrm{~Hz}, \mathrm{PhH}-8), \mathrm{M} 8.03(1 \mathrm{H}, \mathrm{s}, \mathrm{ArH}-8), 8.48(1 \mathrm{H}, \mathrm{s}, \mathrm{ArH}-2)$; MS m/z (\%) $282(\mathrm{M}+\mathrm{H})^{+}$; HPLC purity $97.2 \%$.

\subsection{8. $\mathrm{N}^{1}$-(2-Fluoro-9H-purin-6-yl)-6-methoxy-1,2,3,4-tetrahydroquinoline (6b)-} Prepared in the same manner as 6a. Starting with 6-chloro-2-fluoro-9H-purine $(\mathbf{5 b}, 110 \mathrm{mg}$, $0.64 \mathrm{mmol}$ ) and $\mathbf{3}(115 \mathrm{mg}, 0.70 \mathrm{mmol})$ in $i$-propanol at reflux for $4 \mathrm{~h}$ to furnish $137 \mathrm{mg}$ of 
6b in 73\% yield, white solid, mp $218-220{ }^{\circ} \mathrm{C}$; ${ }^{1} \mathrm{H}$ NMR $\delta$ ppm $2.12\left(2 \mathrm{H}, \mathrm{m}, 3-\mathrm{CH}_{2}\right), 2.86$ $\left(2 \mathrm{H}, \mathrm{t}, J=6.8 \mathrm{~Hz}, \mathrm{PhCH}_{2}\right), 3.82\left(3 \mathrm{H}, \mathrm{s}, \mathrm{OCH}_{3}\right), 4.59\left(2 \mathrm{H}, \mathrm{t}, J=6.8 \mathrm{~Hz}, \mathrm{NCH}_{2}\right), 6.71(1 \mathrm{H}, \mathrm{d}$, $J=2.8 \mathrm{~Hz}, \mathrm{PhH}-5), 6.77(1 \mathrm{H}, \mathrm{dd}, J=8.8$ and $2.8 \mathrm{~Hz}, \mathrm{PhH}-7), 7.54(1 \mathrm{H}, \mathrm{d}, J=8.8 \mathrm{~Hz}$, $\mathrm{PhH}-8), 7.93(1 \mathrm{H}, \mathrm{s}, \mathrm{ArH}-8)$; MS m/z (\%) $300(\mathrm{M}+\mathrm{H})^{+}$.

\subsection{9. $\mathrm{N}^{\mathbf{1}}$-(2-Aminopurin-9H-6-yl)-6-methoxy-1,2,3,4-tetrahydroquinoline (6c)-} Prepared in the same manner as 6a. Starting with 2-amino-6-chloro-9H-purine (5c, $150 \mathrm{mg}$, $0.89 \mathrm{mmol})$ and $\mathbf{3}(160 \mathrm{mg}, 0.98 \mathrm{mmol})$ in $i$-propanol for $4.5 \mathrm{~h}$ to obtain $157 \mathrm{mg}$ of $\mathbf{6 c}$ in $61 \%$ yield, white solid, mp $183 \sim 186{ }^{\circ} \mathrm{C} ;{ }^{1} \mathrm{H}$ NMR (DMSO- $\left.d_{6}\right) \delta \mathrm{ppm} 1.85\left(2 \mathrm{H}, \mathrm{m}, 3-\mathrm{CH}_{2}\right)$, $2.73\left(2 \mathrm{H}, \mathrm{t}, J=6.0 \mathrm{~Hz}, \mathrm{PhCH}_{2}\right), 3.69\left(3 \mathrm{H}, \mathrm{s}, \mathrm{OCH}_{3}\right), 4.33\left(2 \mathrm{H}, \mathrm{t}, J=6.0 \mathrm{~Hz}, \mathrm{NCH}_{2}\right), 5.72$ $\left(2 \mathrm{H}, \mathrm{bs}, \mathrm{NH}_{2}\right), 6.66(2 \mathrm{H}, \mathrm{m}, \mathrm{PhH}), 7.32(1 \mathrm{H}, J=8.8 \mathrm{~Hz}, \mathrm{PhH}), 7.70(1 \mathrm{H}, \mathrm{s}, \mathrm{ArH}), 12.22$ $(1 \mathrm{H}, \mathrm{s}, \mathrm{NH})$. MS $m / z(\%) 297(\mathrm{M}+\mathrm{H})^{+}$; HPLC purity 94.5\% (elution $\mathrm{CH}_{3} \mathrm{CN} /$ water 70:30).

\subsubsection{0. $\mathrm{N}^{1}$-(1-Isoquinolin-1-yl)-6-methoxy-1,2,3,4-tetrahydroquinoline (8a)-A} mixture of 1-bromoisoquinoline (7a, $170 \mathrm{mg}, 0.83 \mathrm{mmol})$ and $\mathbf{3}(150 \mathrm{mg}, 0.92 \mathrm{mmol})$ in the presence of $\mathrm{Cs}_{2} \mathrm{CO}_{3}$ (2 equiv.), X-Phos (5\% equiv), and $\mathrm{Pd}(\mathrm{OAc})_{2}$ ( $4 \%$ equiv) in toluene (15 $\mathrm{mL}$ ) was refluxed for $26 \mathrm{~h}$. The mixture was added to EtOAc, unsoluble solid filtered out, and solvent removed under reduced pressure. The crude product was purified on a silica column with gradiant elution (EtOAc/petroleum ether, $0-30 \%$ ) to provide $180 \mathrm{mg}$ of $\mathbf{8 a}$ in $75 \%$ yield, yellow solid, mp $121 \sim 122{ }^{\circ} \mathrm{C} ;{ }^{1} \mathrm{H}$ NMR $\delta \mathrm{ppm} 2.12\left(2 \mathrm{H}, \mathrm{t}, J=6.0 \mathrm{~Hz}, 3-\mathrm{CH}_{2}\right)$, $2.95\left(2 \mathrm{H}, \mathrm{t}, J=6.0 \mathrm{~Hz}, \mathrm{PhCH}_{2}\right), 3.74\left(3 \mathrm{H}, \mathrm{s}, \mathrm{OCH}_{3}\right), 3.86\left(2 \mathrm{H}, \mathrm{t}, J=6.0 \mathrm{~Hz}, \mathrm{NCH}_{2}\right), 6.33$ $(1 \mathrm{H}, \mathrm{d}, J=8.8 \mathrm{~Hz}, \mathrm{PhH}-8), 6.45(1 \mathrm{H}, \mathrm{dd}, J=8.8$ an $2.0 \mathrm{~Hz}, \mathrm{PhH}-7), 6.70(1 \mathrm{H}, \mathrm{d}, J=2.0 \mathrm{~Hz}$, PhH-5), 6.99 (1H, d, $J=8.0 \mathrm{~Hz}, \mathrm{ArH}-4), 7.40(1 \mathrm{H}, \mathrm{t}, J=8.0 \mathrm{~Hz}, \mathrm{ArH}-7), 7.61(1 \mathrm{H}, \mathrm{t}, J=8.0$ $\mathrm{Hz}, \mathrm{ArH}-6), 7.78(1 \mathrm{H}, \mathrm{d}, J=8.0 \mathrm{~Hz}, \mathrm{ArH}-5), 7.93(1 \mathrm{H}, \mathrm{d}, J=8.0 \mathrm{~Hz}, \mathrm{ArH}-8), 8.28(1 \mathrm{H}, \mathrm{s}$, ArH-3); MS $m / z(\%) 291(\mathrm{M}+\mathrm{H})^{+}$; HPLC purity $96.0 \%$.

\subsubsection{1. $\mathbf{N}^{1}$-(4-Isoquinolinyl)-6-methoxy-1,2,3,4-tetrahydroquinoline (8b)-} Prepared in the same manner as 8a. Starting with 4-bromoisoquinoline (7b, $170 \mathrm{mg}, 0.83$ $\mathrm{mmol}$ ) and 3 (150 mg, $0.92 \mathrm{mmol}$ ), $\mathrm{Cs}_{2} \mathrm{CO}_{3}$ (2 equiv), X-Phos (5\% equiv), $\mathrm{Pd}(\mathrm{OAc})_{2}$ (4\% equiv) in toluene $(15 \mathrm{~mL})$ at relux for $14 \mathrm{~h}$ to produce $180 \mathrm{mg}$ of $\mathbf{8 b}$ in $76 \%$ yield, yellow solid, mp 86 88 ${ }^{\circ} \mathrm{C} ;{ }^{1} \mathrm{H}$ NMR $\delta$ ppm $2.11\left(2 \mathrm{H}, \mathrm{t}, J=6.0 \mathrm{~Hz}, 3-\mathrm{CH}_{2}\right), 2.87(2 \mathrm{H}, \mathrm{t}, J=6.0 \mathrm{~Hz}$, $\left.\mathrm{PhCH}_{2}\right), 3.74\left(2 \mathrm{H}, \mathrm{t}, J=6.0 \mathrm{~Hz}, \mathrm{NCH}_{2}\right), 3.73\left(3 \mathrm{H}, \mathrm{s}, \mathrm{OCH}_{3}\right), 6.13(1 \mathrm{H}, \mathrm{d}, J=8.8 \mathrm{~Hz}$, PhH-8), 6.53 (1H, dd, $J=8.8$ and $2.8 \mathrm{~Hz}, \mathrm{PhH}-7), 6.70(1 \mathrm{H}, \mathrm{d}, J=2.8 \mathrm{~Hz}, \mathrm{PhH}-5), 7.65$ $(1 \mathrm{H}, \mathrm{dt}, J=8.0$ and $2.0 \mathrm{~Hz}, \mathrm{ArH}-7), 7.67(1 \mathrm{H}, \mathrm{dt}, J=8.0$ and $2.0 \mathrm{~Hz}, \mathrm{ArH}-6), 7.95(1 \mathrm{H}, \mathrm{dt}, J$ $=8.0$ and $2.0 \mathrm{~Hz}, \mathrm{ArH}-5), 8.05(1 \mathrm{H}, \mathrm{dd}, J=8.0$ and $2.0 \mathrm{~Hz}, \mathrm{ArH}-8), 8.41(1 \mathrm{H}, \mathrm{s}, \mathrm{ArH}-3)$, $9.15(1 \mathrm{H}, \mathrm{s}, \mathrm{ArH}-1)$; MS m/z (\%) $291(\mathrm{M}+\mathrm{H})^{+}$; HPLC purity $98.5 \%$.

5.1.12. 6-Methoxy-3,4-dihydro-2H-1,4' ${ }^{\prime}$-biquinoline (8c)-Prepared in the same manner as 8a. Starting with 4-chloroquinoline (7c, $150 \mathrm{mg}, 0.92 \mathrm{mmol})$ and $\mathbf{3}(165 \mathrm{mg}, 1.01$ $\mathrm{mmol}$ ) in the presence of $\mathrm{Cs}_{2} \mathrm{CO}_{3}$ (2 equiv), $\mathrm{X}$-Phos ( 0.05 equiv), $\mathrm{Pd}(\mathrm{OAc})_{2}$ (0.04 equiv) in toluene $(15 \mathrm{~mL})$ at reflux for $14 \mathrm{~h}$ to furnish $188 \mathrm{mg}$ of $\mathbf{8 c}$ in $71 \%$ yield, yellow solid, $\mathrm{mp}$ $41 \sim 43{ }^{\circ} \mathrm{C} ;{ }^{1} \mathrm{H}$ NMR $\delta \mathrm{ppm} 2.11\left(2 \mathrm{H}, \mathrm{t}, J=6.4 \mathrm{~Hz}, 3-\mathrm{CH}_{2}\right), 2.87\left(2 \mathrm{H}, \mathrm{t}, J=6.4 \mathrm{~Hz}, \mathrm{PhCH}_{2}\right)$, $3.74\left(2 \mathrm{H}, \mathrm{t}, J=6.4 \mathrm{~Hz}, \mathrm{NCH}_{2}\right), 3.77\left(3 \mathrm{H}, \mathrm{s}, \mathrm{OCH}_{3}\right), 6.50(1 \mathrm{H}, \mathrm{d}, J=8.8 \mathrm{~Hz}, \mathrm{PhH}-8), 6.53$ $(1 \mathrm{H}, \mathrm{dd}, J=8.8$ and $2.4 \mathrm{~Hz}, \mathrm{PhH}-7), 6.72(1 \mathrm{H}, \mathrm{d}, J=2.4 \mathrm{~Hz}, \mathrm{PhH}-5), 7.07(1 \mathrm{H}, \mathrm{d}, J=8.0$ Hz, ArH-3), $7.44(1 \mathrm{H}, \mathrm{t}, J=8.0 \mathrm{~Hz}, \mathrm{ArH}-6), 7.68(1 \mathrm{H}, \mathrm{t}, J=8.0 \mathrm{~Hz}, \mathrm{ArH}-7), 7.95$ (1H, d, $J$ 
$=8.0 \mathrm{~Hz}, \mathrm{ArH}-5), 8.11(1 \mathrm{H}, \mathrm{d}, J=8.0 \mathrm{~Hz}, \mathrm{ArH}-8), 8.75(1 \mathrm{H}, \mathrm{d}, J=8.0 \mathrm{~Hz}, \mathrm{ArH}-2) ; \mathrm{MS} m / z$

(\%) $291(\mathrm{M}+\mathrm{H})^{+}$; HPLC purity 95.6\% (mobile elution $\mathrm{MeOH} /$ water 70:30).

5.1.13. 6-Methoxy-3,4-dihydro-2H-1, $\mathbf{8}^{\prime}$-biquinoline (8d)—Prepared in the same manner as 8a. Starting with 8-chloroquinoline (7d, $550 \mathrm{mg}, 3.37 \mathrm{mmol})$ and $\mathbf{3}(570 \mathrm{mg}, 3.49$ $\mathrm{mmol})$ in the presence of $\mathrm{Cs}_{2} \mathrm{CO}_{3}, \mathrm{X}$-Phos, and $\mathrm{Pd}(\mathrm{OAc})_{2}$ in toluene $(15 \mathrm{~mL})$ at reflux for $12 \mathrm{~h}$ to provide $598 \mathrm{mg}$ of $\mathbf{8 d}, 61 \%$ yield, yellow solid, mp $86 \sim 88{ }^{\circ} \mathrm{C} ;{ }^{1} \mathrm{H}$ NMR $\delta \mathrm{ppm} 2.00$ $\left(2 \mathrm{H}, \mathrm{t}, J=6.4 \mathrm{~Hz}, 3-\mathrm{CH}_{2}\right), 2.93\left(2 \mathrm{H}, \mathrm{t}, J=6.4 \mathrm{~Hz}, \mathrm{PhCH}_{2}\right), 3.74\left(3 \mathrm{H}, \mathrm{s}, \mathrm{OCH}_{3}\right), 3.74(2 \mathrm{H}, \mathrm{t}$, $\left.J=6.4 \mathrm{~Hz}, \mathrm{NCH}_{2}\right), 6.49(1 \mathrm{H}, \mathrm{d}, J=8.0 \mathrm{~Hz}, \mathrm{PhH}-8), 6.50(1 \mathrm{H}, \mathrm{d}, J=8.0 \mathrm{~Hz}, \mathrm{PhH}-7), 6.65$ $(1 \mathrm{H}, \mathrm{s}, \mathrm{PhH}-5), 7.39(1 \mathrm{H}, \mathrm{t}, J=8.0 \mathrm{~Hz}, \mathrm{ArH}-6), 7.41(1 \mathrm{H}, \mathrm{t}, J=8.0 \mathrm{~Hz}, \mathrm{ArH}-3), 7.45(1 \mathrm{H}, \mathrm{d}$, $J=8.0 \mathrm{~Hz}, \mathrm{ArH}-5), 7.56(1 \mathrm{H}, \mathrm{d}, J=8.0 \mathrm{~Hz}, \mathrm{ArH}-4), 8.15(1 \mathrm{H}, \mathrm{d}, J=8.0 \mathrm{~Hz}, \mathrm{ArH}-7), 8.75$ $(1 \mathrm{H}, \mathrm{d}, J=8.0 \mathrm{~Hz}, \mathrm{ArH}-2)$; MS $m / z(\%) 291(\mathrm{M}+\mathrm{H})^{+}$; HPLC purity $95.2 \%$.

\subsection{Antiproliferative activity assay}

Target compounds were assayed by the SRB method for cytotoxic activity using a HTCL assay according to procedures described previously. ${ }^{25,27}$ The cell line panel included human lung carcinoma (A-549), epidermoid carcinoma of the nasopharynx (KB), P-glycoprotein overexpressing epidermoid carcinoma of the nasopharynx (KBvin), and prostate cancer (DU145). The cytotoxic effects of each compound were expressed as $\mathrm{GI}_{50}$ values, which represent the molar drug concentrations required to cause 50\% tumor cell growth inhibition.

\subsection{Tubulin assays}

Tubulin assembly was measured by turbidimetry at $350 \mathrm{~nm}$ as described previously. ${ }^{28}$ Assay mixtures containing $1.0 \mathrm{mg} / \mathrm{mL}(10 \mu \mathrm{M})$ of tubulin and varying compound concentrations were pre-incubated for $15 \mathrm{~min}$ at $30^{\circ} \mathrm{C}$ without guanosine $5^{\prime}$-triphosphate (GTP). The samples were placed on ice, and $0.4 \mathrm{mM}$ GTP was added. Reaction mixtures were transferred to $0{ }^{\circ} \mathrm{C}$ cuvettes, and turbidity development was followed for 20 min at $30{ }^{\circ} \mathrm{C}$ following a rapid temperature jump. Compound concentrations that inhibited an increase in turbidity by $50 \%$ relative to a control sample were determined.

Inhibition of the binding of $\left[{ }^{3} \mathrm{H}\right]$ colchicine to tubulin was measured as described previously. ${ }^{29}$ Incubation of $1.0 \mu \mathrm{M}$ tubulin with $5.0 \mu \mathrm{M}\left[{ }^{3} \mathrm{H}\right]$ colchicine and 5.0 or $1.0 \mu \mathrm{M}$ inhibitor took place for $10 \mathrm{~min}$ at $37^{\circ} \mathrm{C}$, the time at which about $4060 \%$ of maximum colchicine binding occurs in control samples.

\subsection{Aqueous solubility studies}

Solubility was measured at $\mathrm{pH} 7.4$ by using an HPLC-UV method. A test compound was initially dissolved in DMSO at a concentration of $1.0 \mathrm{mg} / \mathrm{mL}$. Ten microliters of this stock solution was slowly dropped into $990 \mu \mathrm{L}$ of water at $\mathrm{pH}$ 7.4. The mixture was stirred at room temperature for $4 \mathrm{~h}$, and then centrifuged at $3000 \mathrm{rpm}$ for $10 \mathrm{~min}$. The clear water phase was transferred to a vial for analysis by HPLC. For quantification, a model 1200 HPLC-UV (Agilent) system was used with an Agilent Eclipse XDB-C18 column (150 mm $\times 4.6 \mathrm{~mm}, 5 \mu \mathrm{m})$, and the eluent was $\mathrm{MeOH} / \mathrm{H}_{2} \mathrm{O}(80: 20)$ with $0.04 \%$ acetamide. The flow rate was $0.8 \mathrm{~mL} / \mathrm{min}$, injection volume was $20 \mu \mathrm{L}$, and detection wavelength was $254 \mathrm{~nm}$. Aqueous concentration was determined by comparison of the peak area of the saturated 
solution with a standard curve plotted peak area versus known concentrations, which were prepared by solutions of test compound in ACN at 50, 12.5, 3.13, 0.78 , and $0.20 \mu \mathrm{g} / \mathrm{mL}$. Each sample was performed in triplicate.

\subsection{Log P measurement}

One to two milligrams of test compound were dissolved in $1.0-2.0 \mathrm{~mL}$ of $n$-octane to obtain a $1.0 \mathrm{mg} / \mathrm{mL}$ solution. Next, the same volume of water as $n$-octane was added to each vial. The mixture was stirred at $\mathrm{rt}$ for $24 \mathrm{~h}$ and left without stirring overnight. The aqueous and organic phases of each mixture were transferred to separate vials for HPLC analysis. The instrument and conditions were the same as those for water solubility determinations. The $\log \mathrm{P}$ was calculated by the peak area ratio in $n$-octane and in water.

\subsection{Molecular modeling studies}

All molecular modeling studies were performed with Discovery Studio 3.0 (Accelrys). The crystal structure of tubulin in complex with DAMA-colchicine (PDB code: 1SA0) was downloaded from the RCSB Protein Data Bank (http://www.rcsb.org/pdb) for use in the modeling study. CDOCKER was used to evaluate and predict in silico binding free energy of the inhibitors and for automated docking. The protein protocol was prepared by several operations, including standardization of atom names, insertion of missing atoms in residues and removal of alternate conformations, insertion of missing loop regions based on SEQRES data, optimization of short and medium size loop regions with the Looper algorithm, minimization of remaining loop regions, calculation of $\mathrm{pK}$, and protonation of the structure. The receptor model was typed with the CHARMM force field. A binding sphere with a radius of $9.0 \AA$ was defined through the original ligand (DAMA-colchicine) as the binding site for the study. The docking protocol employed total ligand flexibility, and the final ligand conformations were determined by the simulated annealing molecular dynamics search method set to a variable number of trial runs. Docked ligand 4a or 1a was further refined using in situ ligand minimization with the Smart Minimizer algorithm by standard parameters. The ligand and its surrounding residues within the above-defined sphere were allowed to move freely during the minimization, whereas the outer atoms were frozen. The implicit solvent model of Generalized Born with Molecular Volume (GBMV) was also used to calculate the binding energies.

\section{Supplementary Material}

Refer to Web version on PubMed Central for supplementary material.

\section{Acknowledgments}

This investigation was supported by grants 81120108022 and 30930106 from the Natural Science Foundation of China (NSFC) awarded to L. Xie and NIH grant CA177584 from the National Cancer Institute awarded to K. H. Lee. This study was also supported in part by the Taiwan Department of Health, China Medical University Hosptital Cancer Research Center of Excellence (DOH100-TD-C-111-005). K.Y.Hsieh was supported by the Teaching and Learning Excellence Program from Kaohsiung Medical University.

\section{References and notes}

1. Dumontet C, Jordan MA. Nat Rev Drug Discov. 2010; 9:790. [PubMed: 20885410] 
2. Kaur R, Kaur G, Gill RK, Soni R, Bariwal J. Eur J Med Chem. 2014; 87:89. [PubMed: 25240869]

3. Duan YT, Sang YL, Makawana JA, Teraiya SB, Yao YF, Tang DJ, Tao XX, Zhu HL. Eur J Med Chem. 2014; 85:341. [PubMed: 25105922]

4. Zhong B, Lama R, Kulman DG, Li B, Su B. Eur J Med Chem. 2014; 80:243. [PubMed: 24780601]

5. Siemann DW. Cancer Treat Rev. 2011; 37:63. [PubMed: 20570444]

6. Tozer GM, Kanthou C, Baguley BC. Nature Rev Cancer. 2005; 5:423. [PubMed: 15928673]

7. Mason RP, Zhao D, Liu L, Trawick L, Pinney KG. Integr Biol. 2011; 3:375.

8. Wang XF, Xie L. J Int Pharm Res. 2012; 39:445.

9. Dowlati A, Robertson K, Cooney M, Petros WP, Straford M, Jesberger J, Rafie N, Overmoyer B, Makkar V, Stambler B, Taylor A, Waas J, Lewin JS, McCrae KR, Remick SC. Cancer Res. 2002; 62:3408. [PubMed: 12067983]

10. Flynn BL, Gill GS, Grobelny DW, Chaplin JH, Paul D, Leske AF, Lavranos TC, Chalmers DK, Charman SA, Kostewicz E, Shackleford DM, Morizzi J, Hamel E, Jung MK, Kremmidiotis G. J Med Chem. 2011; 54:6014. [PubMed: 21774499]

11. Sirisoma N, Pervin A, Zhang H, Jiang S, Willardsen JA, Anderson MB, Mather G, Pleiman CM, Kasibhatla S, Tseng B, Drewe J, Cai SX. J Med Chem. 2009; 52:2341. [PubMed: 19296653]

12. Wang XF, Tian XT, Ohkoshi E, Qin BJ, Liu YN, Wu PC, Hung HY, Hour MJ, Qian K, Huang R, Bastow KF, Janzen WP, Jin J, Morris-Natschke SL, Lee KH, Xie L. Bioorg Med Chem Lett. 2012; 22:6224. [PubMed: 22932313]

13. Wang XF, Ohkoshi E, Wang SB, Hamel E, Bastow KF, Morris-Natschke SL, Lee KH, Xie L. Bioorg Med Chem. 2013; 21:632. [PubMed: 23274123]

14. Wang XF, Wang SB, Ohkoshi E, Wang LT, Hamel E, Qian KD, Morris-Natschke SL, Lee KH, Xie L. Eur J Med Chem. 2013; 67:196. [PubMed: 23867604]

15. Wang XF, Guan F, Ohkoshi E, Guo WJ, Wang LL, Zhu DQ, Wang SB, Wang LT, Hamel E, Yang DX, Li LN, Qian KD, Morris-Natschke SL, Yuan SJ, Lee KH, Xie L. J Med Chem. 2014; 57:1390. [PubMed: 24502232]

16. Nose A, Kudo T. Chem Pharm Bull. 1984; 32:2421.

17. a) Neumeyer JL, Cannon JG. J Org Chem. 1961; 26:4681.b) Singer RA, Dore M. Org Pro Res Dev. 2008; 12:1261.

18. Perez-Sayans M, Somoza-Martin JM, Barros-Angueira F, Diz PG, Rey JM, Garcia-Garcia A. Cancer Lett. 2010; 295:135. [PubMed: 20418015]

19. Hung HY, Ohkoshi E, Goto M, Bastow KF, Nakagawa-Goto K, Lee KH. J Med Chem. 2012; 55:5413. [PubMed: 22612652]

20. Rubinstein LV, Shoemaker RH, Paull RM, Tosini S, Skehan P, Scudiero DA, Monks A, Boyd MR. J Natl Cancer Inst. 1990; 82:1113. [PubMed: 2359137]

21. Sun LQ, Zhu L, Qian K, Qin B, Huang L, Chen CH, Lee KH, Xie L. J Med Chem. 2012; 55:7219. [PubMed: 22856541]

22. Dorleans A, Gigant B, Ravelli RBG, Mailliet P, Mikol V, Knossow M. Proc Natl Acad Sci USA. 2009; 106:13775. [PubMed: 19666559]

23. Bhattacharyya B, Panda D, Gupta S, Banerjee M. Med Res Rev. 2008; 28:155. [PubMed: 17464966]

24. Ravelli RBG, Gigant B, Curmi PA, Jourdain I, Lachkar S, Sobel A, Knossow M. Nature. 2004; 428:198. [PubMed: 15014504]

25. Boyd, MR. Status of the NCI preclinical antitumor drug discovery screen. In: Devita, VT.; Hellman, S.; Rosenberg, SA., editors. Cancer: Principles and Practice of Oncology Updates. Lippincott; Philadelphia: 1989. p. 1-12.

26. Monks A, Scudiero D, Skehan P, Shoemaker R, Paull K, Vistica D, Hose C, Langley J, Cronise P, Vaigro-Wolff A, Gray-Goodrich M, Campbell H, Mayo J, Boyd M. J Natl Cancer Inst. 1991; 83:757. [PubMed: 2041050]

27. Houghton P, Fang R, Techatanawat I, Steventon G, Hylands PJ, Lee CC. Methods. 2007; 42:377. [PubMed: 17560325]

28. Hamel E. Cell Biochem Biophys. 2003; 38:1. [PubMed: 12663938] 
29. Verdier-Pinard P, Lai JY, Yoo HD, Yu J, Márquez B, Nagle DG, Nambu M, White JD, Falck JR, Gerwick WH, Day BW, Hamel E. Mol Pharmacol. 1998; 53:62. [PubMed: 9443933]

\section{Appendix A. Supplementary data}

Supplementary data associated with this this article can be found in the online version. These data include HPLC purity data of target compounds, representive ${ }^{1} \mathrm{H}$ and ${ }^{13} \mathrm{C}$ NMR spetra, and MOL files of the most important compounds described in this article. 
<smiles></smiles>

Colchicine, $\mathrm{R}=\mathrm{H}$

DAMA-colchicine, $\mathrm{R}=\mathrm{SH}$

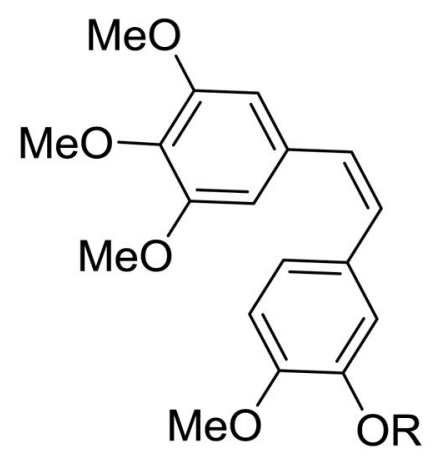

$\mathrm{CA}-4, \mathrm{R}=\mathrm{H}$

CA-4P, $\mathrm{R}=\mathrm{PO}_{3} \mathrm{Na}_{2}$, (phase II/III)<smiles>COc1cc(C(=O)c2c(C)oc3c(O)c(OC)ccc23)cc(OC)c1OC</smiles>

BNC105<smiles>C/C=C\C</smiles>

MPC-6827 (phase II)<smiles>[R]c1nc(N2CCCC(=C)/C2=C/C)c2ccccc2n1</smiles>

New leads 1a, $\mathrm{R}=\mathrm{Cl}$

1b, $\mathrm{R}=\mathrm{NHCH}_{3}$

Figure 1.

Colchicine and analogs, drug candidates of VDAs, and our leads 


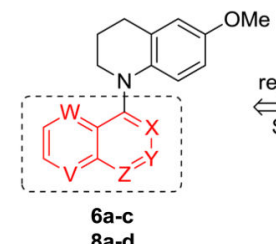

6a-c

$$
\begin{array}{r}
\text { Cytotoxicity } \mathrm{Gl}_{50}(\mathrm{nM}) \\
\text { tubulin assembly } \mathrm{IC}_{50}(\mu \mathrm{M})
\end{array}
$$

$$
\log P
$$$$
\text { WS }(\mu \mathrm{g} / \mathrm{mL}) \quad 0.45
$$$$
\text { HLM }_{1 / 2} \text { (min) } 10.6
$$
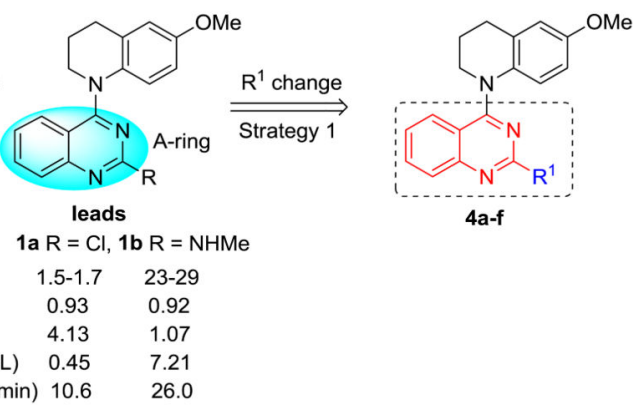

Figure 2.

Leads and optimization strategy 


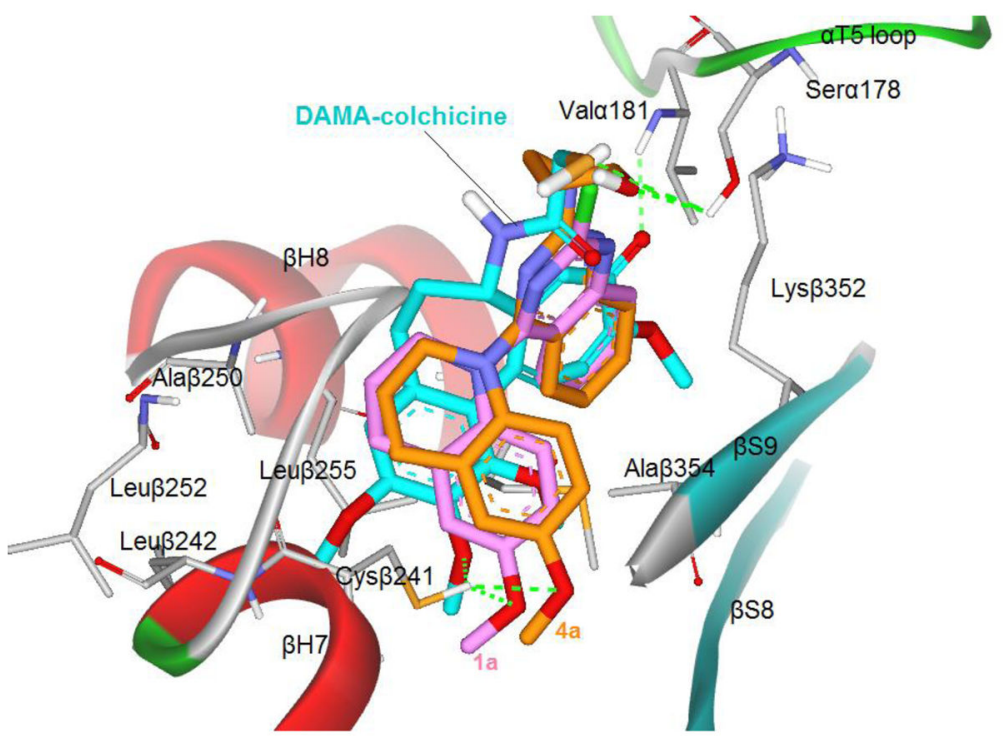

Figure 3.

Predicted modes for $\mathbf{4 a}$ (orange stick for carbon atoms) binding with tubulin (PDB 1SA0) and overlapping with 1a (pink stick for carbon atoms) and DAMA-colchicine (cyan for carbon atoms, the native ligand of 1SA0). Surrounding amino acid side chains are shown in gray stick format and labeled. Hydrogen bonds are shown by green dashed lines, and the distances between ligands and protein are less than $3 \AA$. 

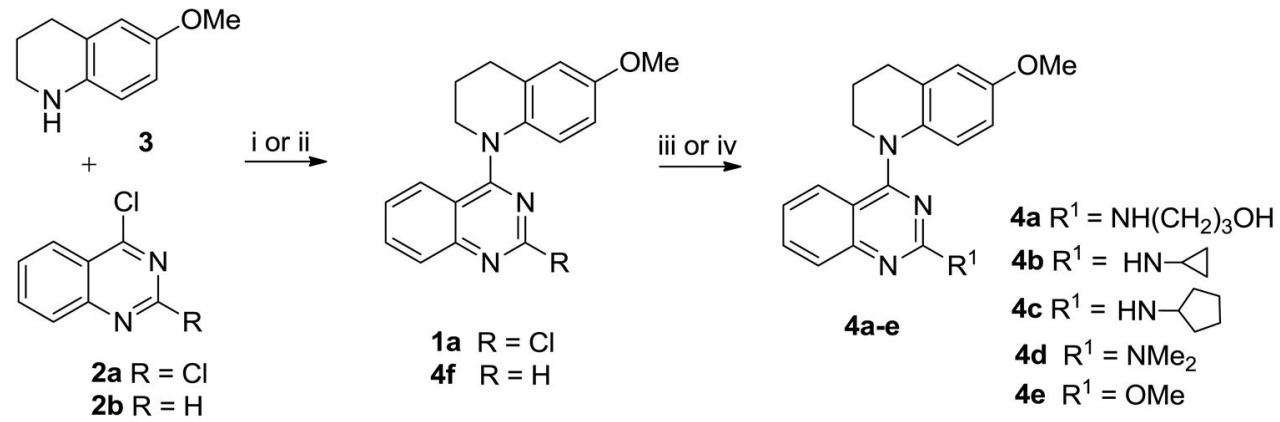

Scheme 1.

(i) $\mathbf{2 a}$, anhydrous EtOH/NaHCO 3 , reflux, $3 \mathrm{~h}$; (ii) $\mathbf{2 b}, i$ - $\mathrm{PrOH} / c \mathrm{HCl}$, reflux, 1 h; (iii) alkylamine, in EtOH or DMF (for 4d), mw, $150{ }^{\circ} \mathrm{C}, 15 \mathrm{~min}$; (iv) $\mathrm{NaOMe} / \mathrm{MeOH}$ (for $4 \mathbf{e}$ ), reflux, $1 \mathrm{~h}$. 

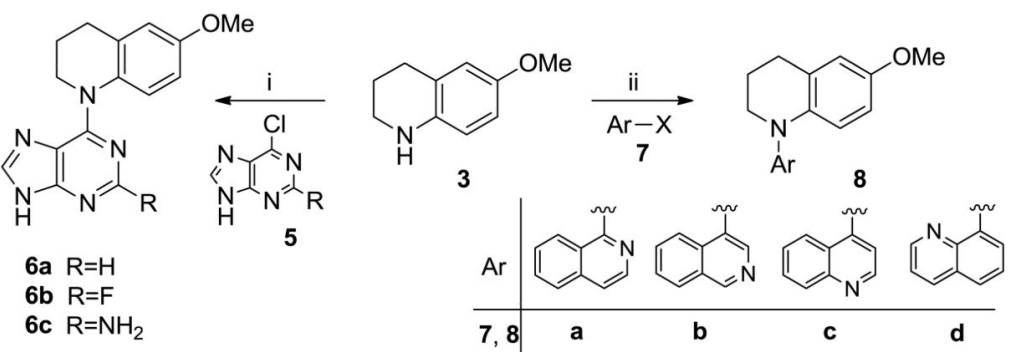

Scheme 2.

(i) $i-\mathrm{PrOH} / \mathrm{cHCl}$, reflux; (ii) $\mathrm{Pd}(\mathrm{OAc})_{2} / \mathrm{X}$-phos (mole ratio $2-4 \%$ ), $\mathrm{Cs}_{2} \mathrm{CO}_{3}$, in toluene reflux. 


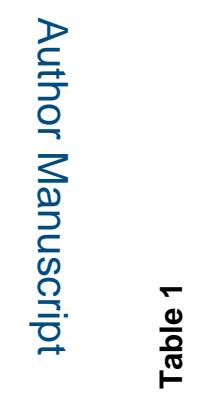

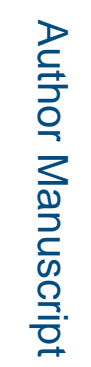

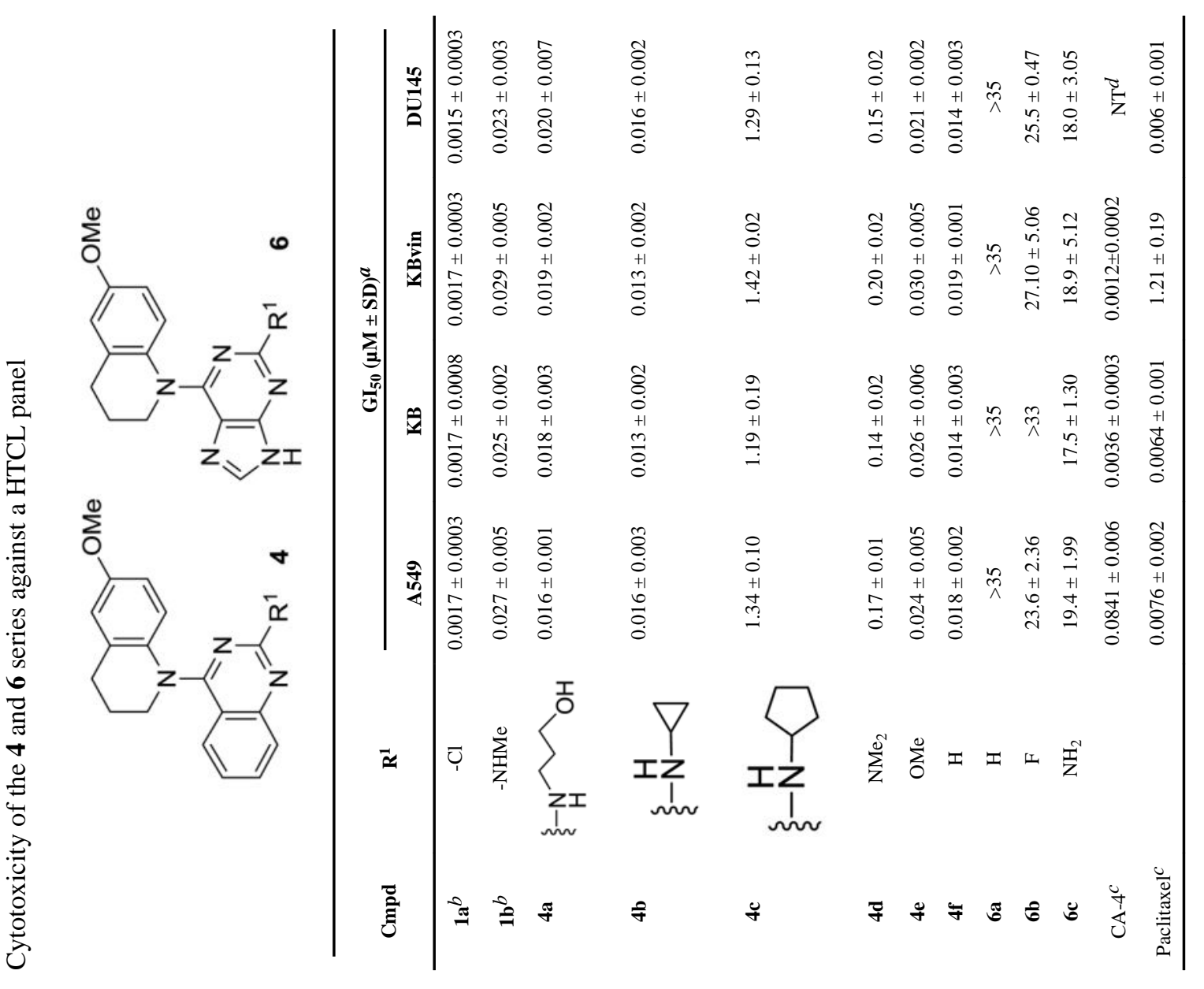

Bioorg Med Chem. Author manuscript; available in PMC 2016 September 01. 

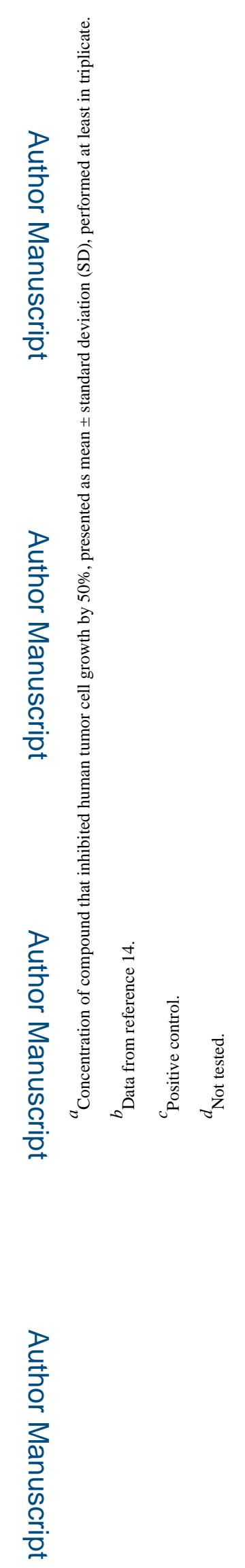

Bioorg Med Chem. Author manuscript; available in PMC 2016 September 01. 

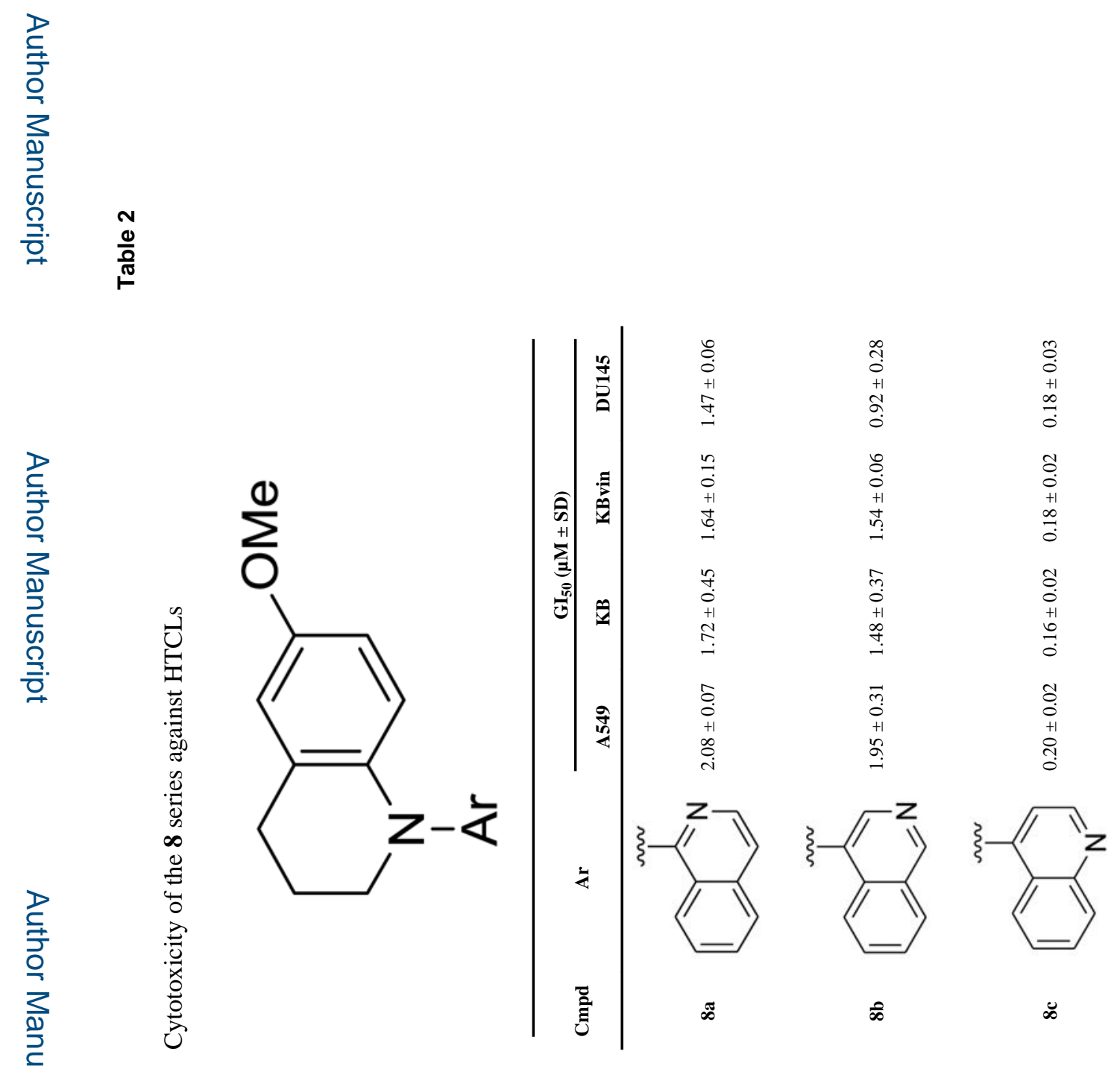

Bioorg Med Chem. Author manuscript; available in PMC 2016 September 01. 


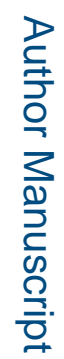

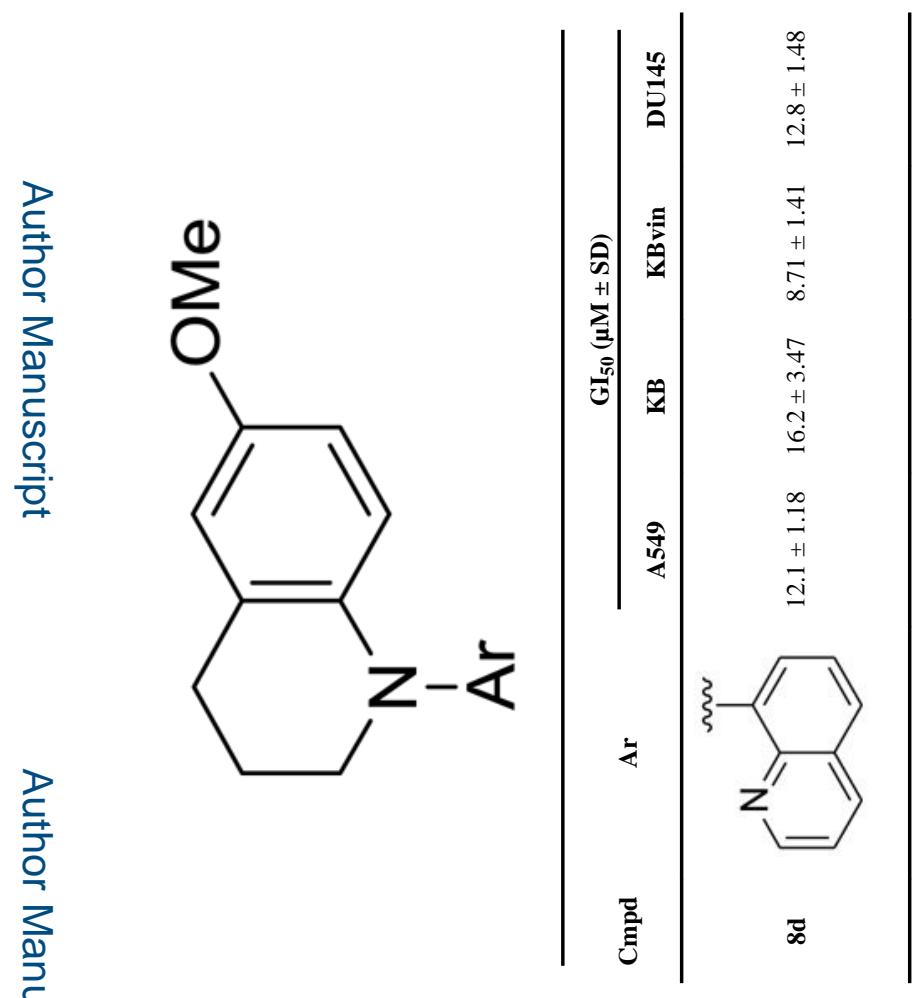

Bioorg Med Chem. Author manuscript; available in PMC 2016 September 01. 
Table 3

Inhibition of tubulin polymerization and colchicine binding to tubulin by selected compounds.

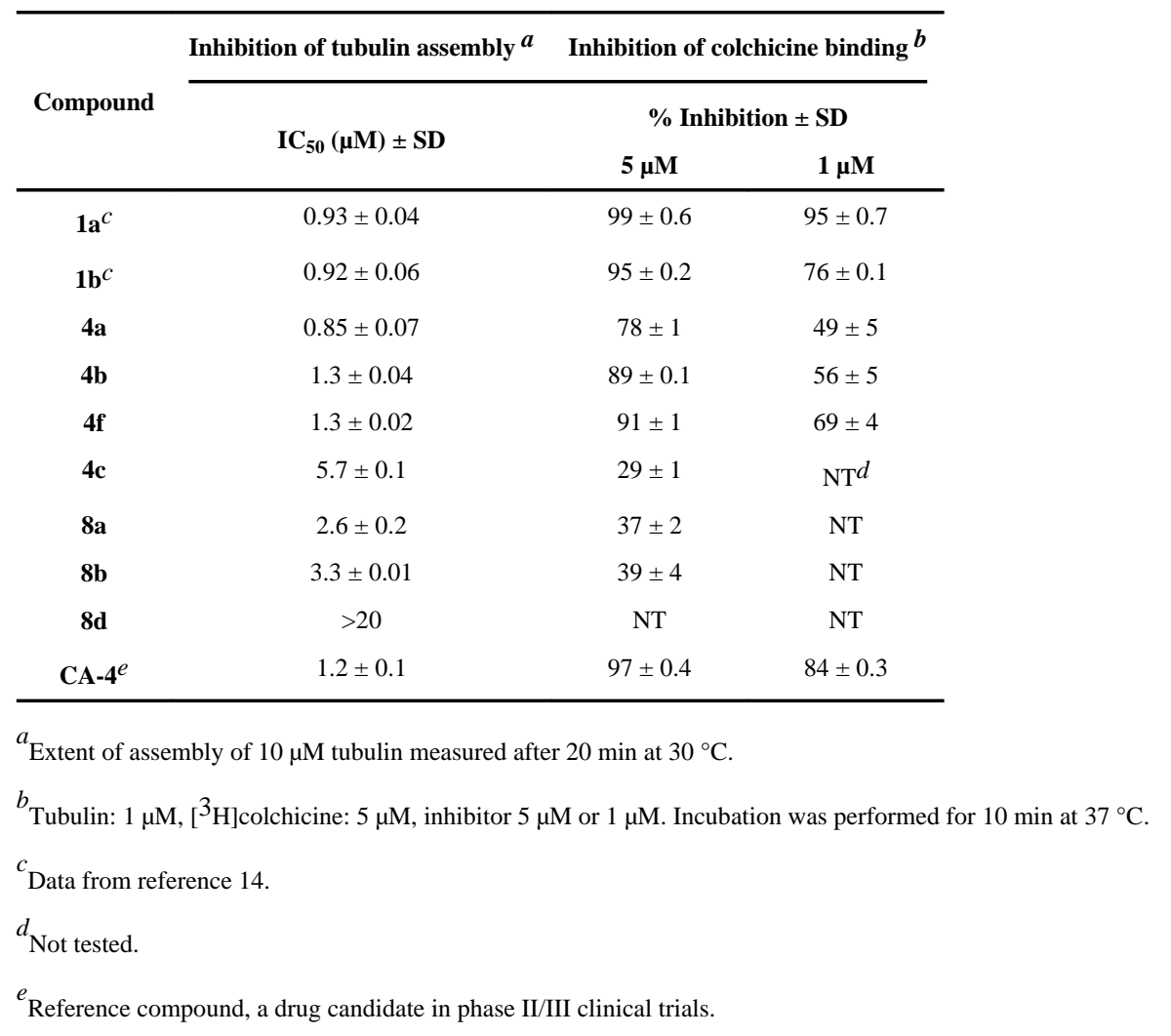

Bioorg Med Chem. Author manuscript; available in PMC 2016 September 01. 


\section{Table 4}

Aqueous solubility and lipophilicity of selected compounds ${ }^{a}$

\begin{tabular}{lll}
\hline Compound & Solubility $(\boldsymbol{\mu g} / \mathbf{m L})$ & $\log \mathbf{P}$ \\
\hline $\mathbf{4 a}$ & $75.6 \pm 0.89$ & $3.43 \pm 0.01$ \\
$\mathbf{4 b}$ & $2.55 \pm 0.27$ & $4.13 \pm 0.03$ \\
\hline
\end{tabular}

${ }^{a}$ Measured at $\mathrm{pH} 7.4$ and presented as mean from three separate experiments with standard deviation $( \pm \mathrm{SD})$. 